\title{
Leadership Communication Style in Improving Public Service Performance (A Case Study of the village office of Camba Berua)
}

\author{
Suhartono
}

Department of Accounting, State Islamic University of Makassar, Indonesia

\begin{abstract}
The purpose of this study is to find out how the communication style applied to the camba village head office is to improve public services, considering that the kelurahan office is one of the closest service offices to the community and is needed by the community. The research method used in this research is descriptive qualitative. The communication style of the leadership at the Camba Berua Urban Village Office uses a familial and flexible communication style that is more directed to the Equalitarian Style, and flexible style.
\end{abstract}

Keywords - Public Service Performance, Leadership Communication.

\section{INTRODUCTION}

As a social creature, communication will never escape from life in general. Communication made the man who had not to know to know, who finally will understand and understand the message that has been delivered to be delivered and can generate feedback that is the interaction. By communicating, people can relate to each other both in daily life, in households, in the workplace, and in the community environment. The importance of communication for humans is undeniable, nor for an organization or company.

Leadership is a process or a person's style to influence others so that the other person will follow what a leader wants. Delivering a message from a leader in his leadership requires proper communication style so that the message conveyed to his subordinates can be well received. A person who holds the position as a leader who has the power or capacity to read the situation precisely faced and adapts to the style of leadership that is owned, so that there is conformity with the demands of the situation faced.

Going well or whether an organization relies heavily on communication that occurs between parts of the organization. As a center of strength and Dynamicator in the organization, leaders must always communicate with all parties. Because the success of implementing these leadership tasks is largely determined by the skills of the leader to establish communication with all parties related to the Organization's activities. Each leader has his own communication style in interacting with his subordinates. Differences in communication styles used by each leader can be influenced by cultural, educational, family environment, experience, and so forth Soemirat \& Ardianto, 1999:8).

The process of communication that occurs in the Government, especially those relating to communication between leaders and subordinates, is an important factor in creating an effective organization. Effective communication depends on how a satisfactory employee relationship is constructed based on a positive climate and trust or organizational atmosphere. In order for this relationship to succeed, there must be trust and openness between the employer and subordinate or vice versa. (Muhammad, 2014:172). The presence of good communication in an organization, an activity can run smoothly and successfully. Effective communication is important to all organizations. Therefore, the leaders of the organization and its communicators need to understand and refine the capabilities of their organization so as to reach the organizational objectives (Kohler, 1981). subordinate or otherwise. (Muhammad, 2014:172). Communication plays an important role in the organization/company. With good communication, an activity of the company and the organization can run smoothly likewise also vice versa, less or absence of communication will be bad in the company or organization. Communication within the organization to provide information to all its members.

In the implementation of its duties, the appropriate means of building cultural organizations, in which communication employees can receive guidance at once can add insight knowledge from the superiors. This factor that causes every individual in the organization is not separated from the nature of the cultural values it is because culture can 
distinguish how to interact, act, and how to finish a job. There are 6 (six) communication styles according to Rohim (2009:115-118) which can be used, among others; The Controlling Style (controlling), The Equalitarian Style (based on similarity), The Structuring Style (structured), the Dynamic Style (Dynamic/aggressive), The Relinquisin Style, The Withdrawal Style.

\section{LITERATURE REVIEW}

\section{Trait Theory}

This Trait Theory believes that people who are born or trained with a particular personality will make them excel in leadership roles. That is, the quality of certain personalities such as courage, intelligence, knowledge, prowess, responsiveness, imagination, physical, creativity, sense of responsibility, discipline and other indigo-values can make a person a good leader.

This leadership theory focuses on the analysis of mental, physical, and social characteristics to gain more insight into the characteristics and combinations of common characteristics among leaders. The success of a person in leadership depends heavily on the nature of his personality and not only from talent but also derived from his experience and learning outcomes.

According to research from McCall and Lombardo (1983), there are four main personality traits that are the determinant of a leader's success or failure.

1.1 Emotional stability and tranquility: calm, confident, and predictable especially during stress.

1.2 Admitted error: Did not cover the mistake that was made but admitted the mistake.

1.3 Good interpersonal skills: able to communicate and convince others without the use of negative tactics and coercion.

1.4 Extensive knowledge (intellectuals): able to understand various areas of understanding only certain areas or specific knowledge

\section{Leadership}

Northouse (2013:5) states that leadership is the process by which individuals affect individual weaknesses to achieve common goals. While Dr. Gunadi Getol defines leadership as a person's ability to influence a group of people who have the same needs and direct them to the author (Getol, 2010:2). According to Richard (in Safaria, 2004:3), leadership is one of the most readily observable phenomena, but one of the hardest things to understand. According to Joseph (in Safaria, 2004:3), leadership is a relationship that affects each other's leaders and followers who want a noticeable change that reflects the purpose of being with him. According to Rifai (2004:2), leadership is the process of influencing and triggering organizational objectives and motivating employee behavior to achieve goals. Leadership involves a profound relationship of influence, occurring among people who desire significant change, and the change reflects the purpose shared by its leaders and followers. The influence (influence) in this case means the relationship between the leader and the follower so that it is not passive, but is a reciprocal relationship and without compulsion. Thus, the leadership itself is a mutually influencing process.

\section{Leader}

Dr. Kartini Kartono (2010:38) provides a leader definition as a person who has the prowess and advantages especially the proficiency in one area - so that he is able to influence others to jointly perform certain activities, in order to access one or more goals. According to Faules (2010:276), a leader is a person who helps others to obtain the desired results. Leaders act in ways that facilitate productivity, high moral, energetic response, quality work prowess, commitment, efficiency, slight weakness, satisfaction, presence, and sustainability in the organization. Leaders can be interpreted as activities to influence the people directed towards achieving the objectives of the organization, the leadership can be formulated as the process of influencing a person's activity or business group toward achieving the objectives in certain situations (Mulyana, 2002:107).

The leader affects his subordinates and vice versa People who are involved in the relationship want a change so that the leader is expected to create significant changes in the organization rather than maintaining the status quo. Furthermore, the change is not something that the leader wants, but more on the purpose (purposes) that is desirable and co-owned. That objective is desirable, expected, to be accomplished in the future so that this goal is the main motivation of the organization's vision and mission. Leaders influence their followers to achieve a change in the form of mutually desired results.

\section{Communication Style}

Corporate According to the Big Bahasa Indonesia dictionary, style is a power that is capable of moving things; strength, ability; Attitudes that mark a person's traits; Specific movements set to attract the attention of others (Chaniago, 2002:207). While the style of the language, according to Chaniago $(2002: 207)$ in its dictionary is a special characteristic that marks the process of disclosure of feelings either orally or in writing.

According to Sutarto (in Tohardi, 2002:300), a behavior approach (Behaviour Theory) or the behavior of a leader is determined by the style of being and acting a leader in question. Behave and acted styles will be seen from:

a. How to give orders 
b. How to Assign Tasks

c. Communication

d. How to make decisions

e. How to encourage a subordinate spirit

f. How to provide guidance

g. How to enforce discipline

h. How to supervise subordinate work

i. How to request reports from subordinates

j. How to lead a meeting

k. How to rebuke subordinate faults, etc.

According to Sutarto (in Tohardi, 2002:300), the measure of success of providing effective leadership communication to the improvement of employee performance needs to be supported by the harmonious cooperation between leaders and employees. Thus, the criteria for measuring the success of communication management include:

a. Clarity of orders and instructions

b. Disclosure (open communication)

c.Acknowledgments and leadership concerns for employees

d. Guidance from leadership for employees

e. Cooperation

According to Mulyasa (2002:165) communication style is defined as a specific set of interpersonal behaviors that are in use in a particular situation (a specialized set of communication behaviors that are used in a given situation).

Each communication style consists of a set of communication behaviors used to obtain specific responses or responses in certain situations. The suitability of a single communication style is used, depending on the intent of the sender and the expectation of the receiver.

According to Mulyasa (2002:165-166), in conducting communication, leaders have their distinctive characteristics in leading their organization. There are six communication styles performed by a leader, namely:

4.1 The Controlling Style

This style is a controlling communication style. The characteristics of this style are regulating and limiting the behavior of its subordinates. This communication style can be characterized by the intention of organizing the minds of other people or people around them. This communication style is known as one-way communications or called one-way communicators. With the use of communication style will complete the task by not going out the path that he should not do, will be on the path that should be in the task or his work.

4.2 The Equalitarian Style
This style is a two-way communication style that is based on aspects of similarity. The characteristic of this communication style is that there is a flow of communications that can be reciprocal. The communication is done openly without any close-cover. Using these communications styles includes effective and will be the same for making decisions on a complex problem.

4.3 The Structuring Style

This style is a communication style that is structured by utilizing verbal messages orally and in writing so that the command to be done is clear, scheduling tasks and work and organizational structure. The sender of the message or sender gives more attention to the desire to be able to influence others by means of sharing information about the organization's objectives, work schedule, rules, and procedures that apply in the organization or within the company. With the use of this communication style will make the process to achieve the objectives become more scheduled or neat according to what has been planned gradually to complete the task or work

4.4 The Dynamic Style

This style is an aggressive communication style, which is often used or done by sales, marketing, and campaigners. It can be said aggressively because the sender's message understands that the environment of its work is oriented towards action. The purpose of the communication style can be said to be aggressive Karen aims to stimulate its subordinates or employees in order to work faster and precisely. This communication style is quite effective when used in addressing critical problems, provided that employees or subordinates have sufficient ability to overcome critical problems. With the use of this communication style will make employees motivated to do their job quickly and precisely, it will help to achieve a common goal.

4.5 The Relinquisin Style

This style is a leader's communication style that can accommodate or receive advice, as well as the opinions or ideas of others than to give commands to their subordinates, even if the sender of the message has the right to give orders to others.

4.6 The Withdrawal Style

The consequences that arise if this style is used is the weakening of the communication, meaning there is no desire of people who use this style to 
contribute to others because there are some problems or difficulties among the people faced by the person.

\section{Employee Performance}

Performance is a term derived from the word job performance or actual performance (a work achievement or actual achievement achieved by a person). Performance (work achievement) is a condition that must be known and addressed to certain parties to determine the level of achievement of the outcome, which is associated with the mission carried by an organization and to know the positive and negative impacts of a policy taken (Ruky, 2004:33). According to Mangkunegara (2005:9) employee performance is the result of work in quality and quantity achieved by an officer in carrying out his duties in accordance with the responsibilities given to him

\section{RESEARCH METHOD}

\section{Types and Approaches to Research}

The research method is a process, principle, and procedure used by a person to approach the problem and find the appropriate solution (Mulyana, 2006:145). Based on the issue above, then the method in accordance with this research is a qualitative method of research. Qualitative research is a study used to investigate, discover, describe, and explain the qualities or privileges of an unexplainable social influence measured or described through a qualitative approach (Saryono, 2010:1). The type of research used in this study is a type of qualitative research based on a descriptive-analytical approach. An analytical descriptive approach is a study conducted by collecting and reusing data with explanations therein. The subject of research is something researched, therefore the subject of this study is the neighborhood's office of Antang .

\section{Research Location}

This research was conducted at Camba Berua Village Office in Makassar

\section{Data Types and Sources}

The data source in this research is primary data. According to Umar (2011:42), primary data is derived from the first source of either individual or individuals such as the result of an interview

\section{Data Collection Method}

The data collection techniques used to assist writers and facilitate the drafting of these studies are using interviews, observation, and documentation data.

\section{RESULTS AND DISCUSSIONS}

In this chapter, researchers explain and describe the research results referring to the identification of the problems found in this research based on the research results that researchers have done in the field. Based on the results of interviews, documentation, and observations in this study, researchers obtained a wide range of information and analysis about the leadership communication style in improving the performance of public services in the office of the Camba Berua.

1. Leadership communication style in improving public service performance in Camba Berua Village office.

The leadership communication style in improving public service performance is very important and must be noticed by each leader. The ability of a leader in determining leadership style is one of the defining factors in the success of improving public service performance. A leader will not be able to implement management, company regulations, and improve public service performed well without the cooperation of all parties contained therein. A leader is a person responsible in all things that will be done and that has been done by his officers. Success in achieving goals is not separated from employee performance, and the performance of employees in the public service itself can be increased through a leadership communication style. Camba Berua District Office leader is striving to the fullest extent possible in improving the performance of public services so that the objectives can be achieved as expected because the success of the public service itself is not entirely done by the leader, but the responsibility of all employees. The communication style is more regarded as a business or an effort to provide understanding and understanding of the activities in the Village office Camba Berua. Looking at the situation and conditions in the office of Camba Berua Village at the moment, then the communication style done by the leader is to use the concept of family, and flexible. Thus, from the results that the authors can in the field, the communication style of the leadership that is found in the office of the Village Camba Berua more towards The concept of The Equalitarian Style that was proposed by Mulyasa, on this concept of communication style based on commonality and in this communication style the act of communication is done openly, meaning that each member of the organization can express ideas or opinions in a relaxed, relaxed and informal atmosphere and thus enable each member of the organization to achieve agreement and mutual understanding.

\section{Family Communication Style}

Based on the results of the research researchers have done, the family communication style that is found in the office of Camba Berua village leads to The Equalitarian Style, the important aspect of this communication style is the 
cornerstone of similarity. The Equalitarian Style is characterized by an enactment of the spread of verbal and written bidirectional messages. In this communication style, communication is done openly, meaning that every employee in the office can express the idea or opinion in a relaxed, relaxed, and informal voice. In such an atmosphere it is possible that every office employee can reach an agreement and understanding together.

In the office of the village of Camba Berua all people who work in it are family. All Office employees must be honored and appreciated for their existence in order to improve public services. Camba Berua's office leader built this communication style since the beginning of his leadership in the office. The office is made as comfortable as possible by leaders so that employees feel at home and consider the office is their own home. Lurah as the leader gave a very important thing for its officers in carrying out its duties so that the employees do not feel overwhelmed with the task given by the leadership. Therefore, the proper communication style determination applied by the leadership greatly affects the performance of employees in improving public services. In the village office problems often occur in it. And how to cope with the problem depends on the attitude of the company leader. As in the headquarters of the Camba Berua, the family communication style applied by the leadership is influential with the performance of public service but not so strong, because employees can procrastinate their work. From the interview, it can be concluded that there are some problems with the family communication style because of the lack of communication style in increasing public service improvement. The positive thing that can be taken from the family communication style is the relationship between leadership and employees.

\section{Flexible Communication Style}

Flexible, simple, and adaptability is the ability to be flexible, easy, and quick to adapt. The ability to follow the flow of communication but still on an effective path must be owned by a leader. Leaders must be able to direct existing communications in accordance with the company's main objectives. In this case, the communication style is flexibly performed by the leadership of the Camba Berua Village office. With a flexible communication style, leadership can put the communication style according to the employee's condition. Leaders do not necessarily communicate with subordinates like a leader. If you are in a meeting with the employee or, the leader uses formal communication, but if in a relaxed state of leadership and the employee communicates informally even in the office of the interview, it is known that the leadership gives employees the freedom to communicate, not necessarily use a formal style in the office, and this flexible communication style is used according to the situation and conditions in the office.

\section{Improve Employee Performance}

Leaders should be able to figure out how to improve public service performance in addition to determining the communication style done within the company. Because the performance of employees in improving public services greatly affects the success of the purpose of a village office.

5. Things influencing the implementation of leadership communication style in improving public service performance

Based on the results of the interview the author did, it clearly appears that in applying the communication style of leadership in the institutions, is influenced by some things such as:

\subsection{How to Give Orders}

Leaders must provide clear orders and tasks in order to be understood by the officers he has ordered. At the village office of Camba Berua itself, the leader gave orders or instructions very clearly to the subordinates, and the leader always tried to not offend the subordinate subordinates to the rule that the ruled was pleased with what the superiors ordered and run with no sense of forced at all.

"Usually it is if I give orders to the subordinate must ensure first if the subordinate I have understood what I commanded so that in the order I give can be done well, if not in love so much if he works twice because the results are not in accordance with the command, and I also if the command is not strained, give a joke in the sidelines my command so the, so it's not too burdened with the commands I've given "(Interview results). Thus the ruled subordinate can accomplish its task very well so that it can improve the performance of public services.

\subsection{How to communicate}

The types of communication that are usually done to the subordinate can be formal communication and informal communication such as in the Office of the village Camba Berua, the leader to free employees in communicating as long as employees can see the situation.

"If we are here, do not require to always use formal language. If the staff used informal language is permissible because it is strange that the formal language is still we know each other. New formal language is used when guests "(interview result).

Its leadership in communicating strongly affects the communication style that is done because the proper 
communication style can make the message delivered well-received by the employee

\subsection{How to make decisions}

Decision-making is essentially the mature determination of the various problems faced and taking actions that according to calculations is the most appropriate action. Before making a decision, the leader should seek to know in advance the root of the problem, then analyze, then determine the attitude to the problem.

"If we are here, always counsel when there is a problem encountered. If I myself make a decision on that problem there must be nothing in line. So we discussed first to find a good idea of what this problem is "(interview results).

So that in the office of Camba Berua Village, the leader is open in terms of giving input to the problems that occur. Thus, indirect subordinates can assist the leader in resolving problems. The problem is always discussed with the subordinates in order to be able to determine the way to outside the best for the smooth work, but still decisions in the hands of the institutional leadership.

5.4 How to provide guidance

Guidance and direction undertaken by the leadership to the subordinates greatly affect the performance of public service. Because not all of the subordinates immediately understand their duties and responsibilities, therefore they desperately need guidance from their leaders in completing their duties.

"Usually the guidance is given by new officers in the office of the Village Camba Berua, because the deciding from the future of the assignment of a person is determined from the beginning they work, if we give the wrong guidance then it will affect the future. So we get in the habit of guiding someone from the beginning so that our future is not half-dead "(interview results). By using the right communication style, employees can receive job guidance from the leadership more quickly.

5.5 How to enforce discipline

In the office of Camba Berua Village, the leader gave some sanctions to the subordinates who are not disciplined.

"If we here are very disciplined presence problems, here we already used the application which is the substitute manual absent. This is a face scan that must be accompanied by a location so that we can monitor the subordinates about attendance, well if they do not give heed to the discipline of the presence, I usually give sanctions in the form of strikes "(interview results).

5.6 How to supervise subordinate work

In the office of the Camba Berua Village, Lurah supervised the subordinate's work through direct supervision and indirect supervision.

"If the way I watched from the subordinate in a direct and indirect way. Sometimes I pretended to be out of the room for a call to see what my subordinates were doing. If I were busy with my work, I also never forgot to keep an eye on the subordinates I usually ask one of my beliefs about what my subordinates are doing "(interview results).

Direct supervision is used by the leader to see the subordinates ' performance and indirect supervision in the form of reports from secretaries and village treasurer.

5.7 How to rebuke subordinate mistakes

At the administrative office of Camba Berua, the leadership immediately rebuked the wrongdoing by subordinates, because if through intermediaries would usually cause bad taste by subordinates.

"Usually if there is a subordinate who made a mistake, I usually call the subordinate to my table, then I invite him to talk if he has an outside problem until his job is interrupted or how, if they have problems outside the office I usually advise to not mix between office problems and out of office because it will adversely affect their work" (Interview results).

The way to rebuke the leadership will impact the psychology of a subordinate. Many subordinates did not feel at home in a place because of the problem of reprimanding his leadership, moreover for someone who has a mental that is not strong. Because everyone can not escape the wrong name, then a leader will adjust how to rebuke someone and the character of someone.

\subsection{Experience}

The leadership experience in the lead greatly affects the success of the leadership in using communication styles to improve the performance of public servants within the village office.

"Usually we do lunch together in a week can be up to 2-3 times. That's when we usually share things about their experiences. In this way, I think that I can add a sense of family among us, which is between the leader and subordinate "(interview results).

Because, with experience, leadership can give advice, motivation, and input to improve the performance of its employees.

5.9 Open to each other 
Between the leadership and subordinates of the office Lurah Camba Berua each other open in communicating.

"As I said earlier, we usually do lunch together at that time we did a conversation without a formal language, so the subordinates will feel more comfortable in the environment of the village Camba Berua because the sense of the family is high" (interview results).

This is done so that all the anxiety and thought from the subordinates can be resolved and with the open interlocking attitude between the leader and subordinate. In addition, transparency from leadership can help improve the performance of public services.

\section{Supporting and inhibitory factors}

Factors that are a contributing factor of the leadership communication style and work motivation to improve the performance of public services in the office of the village Camba berua, among others:

Employee factors, including:

6.1 Communication between employees who went well. With communication between employees who went well, facilitating employees to coordinate and build relationships between employees and others can help each other and assist in working.

6.2 Comfortable working environment. The working environment is an important role in supporting employees working. However, in the village of Camba, the working environment becomes an environment that does not need to be feared anymore because there has been a warm environment where all employees gathered in one workspace according to each work desk.

6.3 Support facilities and infrastructures adequate work. Facilities and infrastructure have a role in supporting employees working. Because with the adequate facilities and infrastructures, it will make it easier for employees to finish their work. In Kelurahan Camba, facilities and infrastructures are unnecessary to complain again because in this village facilities and infrastructures that support the work are all available. So what is needed is already there.

6.4 High participation from the community. The participation of the community in Kelurahan Camba Berua in support of every activity in the village is a factor that has its own in determining the success or absence of the activity. To date, every activity held by the village is high community participation.
The factors that become a factor in the communication style of the leader in improving the performance of public services in the office of the Village Camba Berua, including:

6.5 The communication style of the leader is ineffective. In the lead, communication is important in supporting the success of leadership. Therefore, the communication style of the leader used by the leadership of Camba has not been so able to be a bridge connecting and building relationships with employees.

6.6. There are gaps between leaders and employees. As a regional device work unit (SKPD) at the village level, it is supposed to demonstrate the solidarity in working and understanding in determining and looking at something. Camba Berua Village Office is no longer available

\section{CONCLUSION}

Based Based on the results of the interviews and the data researchers have gained discussing the leadership communication style in improving the performance of public services in the office of the village Camba Berua then researchers can draw conclusions as follows:

1. The communication style of the leadership at the Village office of Camba Berua uses a family and flexible communication style that further leads to The Equalitarian Style, where The Equalitarian style is communication is done openly, meaning that each member of the organization can express ideas or opinions in a relaxed, relaxed and informal atmosphere. In such an atmosphere it is possible for each member of the organization to reach an agreement and understanding together.

2. The communication style of the leadership in the administrative office of Camba Berua is running well in its application and able to deny the performance of public services.

3. Support facilities and infrastructures adequate work. Facilities and infrastructure have a role in supporting employees working. Because with the adequate facilities and infrastructures, it will make it easier for employees to finish their job. In the office of the village Camba berua, facilities and infrastructures are not necessary to complain again because in this village facilities and infrastructures that support the work is available. So what is needed is already there.

4. As for the factors that become a factor of the communication style of the leader in improving the performance of public services in the office of the village Camba Berua, the communication style of the leader is ineffective. And there is a gap between the leader and the officers.

Limitation of research- Due to limited research time, we 
did not have many times interviewed the staff. We only ask for the basics of how the leader performs a subordinate communication

Advice. For further research, researchers should do research other than to know the communication style also to research what is the performance improvement that occurs when communicating with different communication styles.

\section{REFERENCES}

[1] Agus Yudi Harsono, Supratomo, Muhammad Farid. 2015.Analisis Gaya Kepemimpinan Dan Komunikasi Organisasi Antara Atasan-Bawahan DalamMembangun Budaya Organisasi Di LingkunganSekretariat Dprd Kota Bengkulu. Jurnal Komunikasi Kareba Vol. 4 No.

[2] Ardiansyah, Firman. (2011).Pengaruh Gaya KomunikasiPemimpin Terhadap Kepuasan Kerja Karyawan

[3] Deddy, Mulyadi \& Veithzal Rivai. 2011. Kepemimpinan dan Perilaku Organisasi. Jakarta : PT. Raja Grafindo Persada

[4] Faules, R. Wayne Pace Don F. 2010. Komunikasi Organisasi. Bandung: PT. Remaja Rosdakarya.

[5] http://kepemimpinan.wordpress.com, diakses 16 Agustus 2013 pukul 15.00 WITA

[6] Kriyantono, Rachmat, 2008, Teknik Praktis Riset Komunikasi: Disertai Contoh Praktis Riset Media, Public Relations, Adverstising, Komunikasi Organisasi, Komunikasi Pemasaran, Kencana, Jakarta

[7] Kriyantono, Rachmat. 2008. Teknik Praktis Riset Komunikasi : Disertai Contoh Praktis Riset Media, Public Relations, Advertising, Komunikasi Organisasi, Komunikasi Pemasaran. Jakarta : Kencana Prenada Media Group.

[8] Liliweri Alo. 2011. Komunikasi Serba Ada Serba Makna, Jakarta: Kencana Prenada Media Group.

[9] Malina nur dini. 2015. Gaya Komunikasi Pimpinan Pt Karya Prima Mandiri Abadi Communication Style Of Pt Karya Prima Mandiri Abadi's Leaders. e-Proceeding of Management: Vol.2, No.3.

[10] Muhammad, Arni. 2007. Komunikasi Organisasi. Jakarta: Bumi Aksara

[11] Musmuh, Abdullah, 2013, Komunikasi Organisasi Dalam Perspektif Teori Dan Praktek, UMM Press (UPT Penerbitan Universitas Muhammadiyah Malang), Malang

[12] Pace, Wayne \& Don F. Faules. 2001. Komunikasi Orgranisasi. Bandung : PT. Remaja Rosdakarya

[13] Pace, Wayne \& Faules, Don. 2010. Komunikasi Organisasi. : Strategi Meningkatkan Kinerja Perusahaan.Bandung : PT Remaja Rosdakarya. 190

[14] Ramli. 2015. Gaya Komunikasi Pemimpin Dan Motivasi Kerja Dalam Meningkatkan Kinerja Pelayanan Publik. JISIP: Jurnal Ilmu Sosial dan Ilmu Politik ISSN. 2442-6962 Vol. 4, No. 1

[15] Sherwyn dkk. 2007. Human Communication: Motivation, Knowledge, and Skills, Second Edition. USA : Thomson Higher Education

[16] Tubbs, Stewart \& Sylvia Moss. 2005. Human Communication. Bandung : PT. Remaja Rosdakarya.
[17] Wulandari putri.2015.Gaya Komunikasi Pimpinan Dalam Meningkatkan Kinerja Karyawan Pada Pt. White And Blue Di Pekanbaru. Jom FISIP Volume 2 No. 1

[18] Yukl, Gary. (2009). Kepemimpinan Dalam Organisasi. Jakarta:PT Indeks 